\title{
Mathematical Reasoning Ability and Learning Independence of High School Students Through Problem Based Learning Model
}

\author{
Purnama Putra1,a ${ }^{*}$, M. Ikhsan ${ }^{1, b}$ \\ 1 Department of Mathematics Education, Syiah Kuala University, Jl. Teungku Chik Pante Kulu No. 5 Banda Aceh 23111,Indonesia \\ purnamaputra32@gmail.com; ikhsan@unsyiah.ac.id \\ ${ }^{*}$ Corresponding Author \\ Whatsapp Number [ 085277013123]
}

How to Cite : Putra, P., Ikhsan, M. (2019). Mathematical Reasoning Ability and Learning Independence of High School Students Through Problem Based Learning Model. International Journal for Educational and Vocational Studies, 1 (3), 217-223.

\section{ARTICLE HISTORY}

Received:13 June 2019

Revised: 23 June2019

Accepted: 26 July 2019

\section{KEYWORDS}

Problem Based Learning Model, Mathematical Reasoning,

Student Learning Independence

\begin{abstract}
The ability of students to answer mathematical reasoning questions and to learn independence is still low. Mathematical reasoning and learning independence are important possessed by students. Therefore, a learning model of a relevant. One of the learning approaches is the Problem Based Learning (PBL) model. The purpose of the study to find out: Differences in the increase in mathematical reasoning abilities and student learning independence taught by using PBL with students taught with conventional learning in terms of (a) all students, and (b) student level (high, medium, low). This research is an experimental research design with a pretest-posttest control group design. The population of this study was all students of class $X$ of the Delima 1 High School in Pidie. While the sample consisted of two classes, namely the experimental class (X-2) and the control class $(X-3)$ taken by random sampling. The instrument used to obtain research data is a test of mathematical reasoning ability and student learning independence. To see the difference in mathematical reasoning abilities and student learning independence between classes PBL models with conventional classes using the t-test. The results showed that the improvement of students' mathematical reasoning abilities and student learning independence that obtained learning with PBL approach was better than students who obtained learning with conventional approach in terms of overall and initial abilities of students (high, medium, low), in quality there were significant differences between students who studied using PBL model with those using conventional learning.
\end{abstract}

\section{INTRODUCTION}

Mathematics is a science that is important for all students to learn, from elementary school to high school even in college. Many reasons for the need for students to learn mathematics, among others, because mathematics is a means of logical and mathematical thinking, a means of developing creativity, a means of recognizing patterns of relationships and generalization of experience and a means of solving problems in everyday life. Mathematics learning aims so that students have the ability, one of which is reasoning ability. Students' reasoning abilities are formed through activities to identify patterns and traits, make mathematical manipulations in generalizing, compiling evidence, or explaining mathematical ideas and statements (Permendiknas No. 22 of 2006). This is in accordance with the objectives of mathematics subjects in the 2013 Curriculum, so that students have high-level thinking skills such as problem solving skills, reasoning and communication (Nurani, 2014).
One of the goals of mathematics learning in the curriculum in Indonesia is reasoning and proof. NCTM (2000) states that mathematical reasoning ability is an ability that supports a student to be able to develop and express their knowledge about a phenomenon both concepts and mathematical principles at hand. This is consistent with the explanation of Turmudi (2008) saying that mathematical reasoning ability is a habit of the brain as well as other habits that must be developed consistently using various kinds of contexts, recognizing reasoning and proof are fundamental aspects in mathematics

Nurani (2014) argues that reasoning is a process of drawing conclusions that connect facts or evidences that are known to reach a conclusion. Conclusions obtained through the reasoning process can be used as a pathway to solving problems or stimuli to bring up new ideas or ideas. This is in line with the opinion of Turmudi (2008) that the reasoning aspect should be an important aspect in mathematics learning. Reasoning skills need to be able to 
pay attention in implementing mathematics learning.

Therefore, students must understand the indicators of mathematical reasoning abilities, among others, students can (1) draw logical conclusions, (2) provide explanations with models, facts, traits and relationships, (3) estimate answers and process solutions, (4 ) Using patterns and relationships to analyze mathematical situations, (5) Developing and testing conjectures, (6) Formulating counter examples (counter example), (7) Following inference rules, checking the validity of arguments, (8) Arranging valid arguments, and (9) Arrange direct, indirect, and use mathematical induction.

In addition to mathematical reasoning abilities, psychological factors also play a role in the success of students in achieving the goals of mathematics learning. These psychological factors include learning independence. This refers to the 2013 curriculum, (Permendikbud No. 65 of 2013 that the mathematics learning process should need to pay attention to the state of the students including independence.

Pannen (2000) emphasizes that the main feature in independent learning is not the absence of teachers or fellow students, or the absence of face-to-face meetings in class. The main feature of independent learning is the development of the ability of students to carry out learning processes that are not dependent on factors such as teachers, friends, class and others. The level of student learning independence can be determined based on the size of the initiative and the responsibility of students to play an active role in terms of learning planning, learning processes and evaluation of learning. The greater the student's active role in learning indicates that the student has a high level of learning independence.

Realizing the importance of mathematical reasoning skills and learning independence in students, teachers are expected to seek learning by applying learning strategies that can provide opportunities and encourage students to practice mathematical reasoning skills and learning independence. Teachers need to apply learning that supports students to reason independently.

One of the lessons that provides opportunities for students to reason and be independent is learning with Problem-Based Learning (PBL) models. Learning using the Problem-Based Learning (PBL) model is done by providing stimuli in the form of non-routine problems. According to Amir (2010), PBL is one of the innovative learning models that can involve active students in solving problems through scientific stages as well as helping students learn knowledge about the problem so that they have the skills and kemadirian student learning in problem solving.

The PBL model is appropriately applied to improve mathematical reasoning and student learning independence by using learning concepts that link the material taught with students' real world situations and encourage students to make connections between their knowledge and their application in their daily lives using the process of mathematical reasoning. This requires students to be independent in learning so that students will not feel hopeless in facing problems and encourage students to choose a suitable strategy to solve the problem (Sugandi, 2013).

Learning reasoning and independence requires a student-centered learning, making students more active and accustomed to independent learning. One learning that meets these criteria is Problem-Based Learning (PBL). The 2013 curriculum implementation training module (Kemendikbud, 2013) explained that the problem-based learning model was carried out by providing stimuli in the form of problems which were then solved by students who were expected to add students' skills in achieving learning material. In the PBL model, problems are the main source of learning. In addition to building concepts, problems can be used as examples to stimulate students to be active in learning.

The core activities in PBL that have been carried out by the Ministry of Education and Culture are one of the important factors in improving reasoning abilities and forming student learning independence. This is in accordance with what was stated by Wena (2009) that core learning activities are the most influential activities in improving student learning outcomes. One of PBL's core activities that can improve reasoning ability is in phase 5 to analyze and evaluate the problem solving process. In line with the Ministry of Education and Culture, Ibrahim (2011) states that the core activities in PBL have a great opportunity for students to use reasoning on patterns and traits, make mathematical manipulations in generalizing, compiling evidence or explaining ideas. In addition, one of the advantages of the PBL model is quoted from the Center for Instructional Development Researches-CIDR that problem-based learning can develop long-term independence and learning skills. Based on the description of problem-based learning, it can be seen that the PBL model can provide stimuli or stimuli to students to do reasoning and form learning independence. In addition, Pape and Bell (Surya, 2013) state that increasing thinking, performance and self-reflection on student learning independence will improve reasoning.

\section{METHODS}

The type of research used in this study is experimental research that is research that seeks to influence the influence of certain variables on other variables in tightly controlled conditions. The design used in this study is the Pretest-Posttest Design Group Control, namely research involving two sample classes. Before being treated, members of the study sample were first given the initial test (pretest) with the aim of knowing students' initial knowledge of the subject matter to be studied.

The population in this study were all students of class $\mathrm{X}$ of the Delima 1 Senior High School in Pidie District in the 2018/2019 Academic Year. The research sample was taken by random sampling from all students of class $\mathrm{X}$, namely 
one class as a trial class and two classes for actual research namely class X2 as the experimental class and X3 as the control class. The learning experimental class is carried out with the PBL model, while the other classes are the control class that get regular or conventional learning.

\section{RESULTS AND DISCUSSION}

\section{Results}

In accordance with the formulation of the problem, the results of this study describe the reasoning ability and student learning independence towards the Problem Based Learning approach. Increasing students' reasoning and independence of learning abilities can be seen in the table of test results in differences in the average reasoning ability and student learning independence shown in the table below.

Table 1. Difference Test Results of N-Gain Reasoning Ability

\begin{tabular}{llll}
\hline Class & t-Count & Sig. (2-tailed) & Conslusion \\
\hline Eksperimental & 1,795 & 0,078 & $\mathrm{H}_{0}$ Refused \\
\hline Control & & & \\
\hline
\end{tabular}

Because the value of Sig. (1-tailed) < Significance level a $=0.05$ so that H0 is accepted. This means that there is no significant difference between the experimental class pretest score and the control class pretest score. So, it can be concluded that these two classes have the same initial abilities. $\alpha$ Based on table 1.1 shows that the value of sig. (2-tailed) pretest data is 0.078 which means more than.

Table 2. Difference Test Results of N-Gain Student Learning Independence

\begin{tabular}{llll}
\hline Class & t-Count & Sig. (2-tailed) & Conclusion \\
\hline Eksperimental & \multirow{2}{*}{1,690} & 0,096 & H$_{0}$ Refused \\
\hline
\end{tabular}

Based on table 1.2 it can be seen that on N-Gain normalized student learning independence with values $\mathrm{t}=$ 1,690 and Sig. (2-tailed) $=0.096$. Because according to Uyanto (2009: 145) do a one-sided hypothesis test (1-tailed) then the Sig. (2-tailed) must be divided into Sig. (1-tailed) $=$ 0.048. Because the value of Sig. (1-tailed) < Significance level $(\alpha=0.05)$, then H_odirefused. So it can be concluded that the average $\mathrm{N}$-Gain normalized learning independence of the experimental class rank is better than the control class N-Gain average. The results of testing the hypothesis above can be concluded that the increase in learning independence of students who get learning with the PBL approach is better than the learning independence of students who get conventional learning.

For grouping students are taken based on the N-Gain value obtained by students. The grouping of students is divided into three, namely high, medium, low. To see the difference in the increase in spatial ability and understanding of high group students in the experimental class with (high, medium, low) control class, the difference test was conducted. The results of the N-Gain difference test are presented in the table below:

Table 3. Difference Test Results Average N-gain Reasoning Capability reviewed based on Student Level

\begin{tabular}{|c|c|c|c|c|}
\hline Class & Group & t-Count & $\begin{array}{l}\text { Sig. } \\
\text { (2-tailed) }\end{array}$ & Conclusion \\
\hline Eksperimental & High & \multirow{2}{*}{0.814} & \multirow{2}{*}{.425} & \multirow{2}{*}{ Accepted $\mathrm{H}_{0}$} \\
\hline Control & High & & & \\
\hline Eksperimental & High & \multirow{2}{*}{18.322} & \multirow{2}{*}{.000} & \multirow{2}{*}{ Refused $\mathrm{H}_{0}$} \\
\hline Control & Medium & & & \\
\hline Eksperimental & High & \multirow{2}{*}{32.783} & \multirow{2}{*}{.000} & \multirow{2}{*}{ Refused $\mathrm{H}_{0}$} \\
\hline Control & Low & & & \\
\hline Eksperimental & Medium & \multirow{2}{*}{-11.976} & \multirow{2}{*}{.000} & \multirow{2}{*}{ Refused $\mathrm{H}_{0}$} \\
\hline Control & High & & & \\
\hline Eksperimental & Medium & \multirow{2}{*}{2.091} & \multirow{2}{*}{.044} & \multirow{2}{*}{ Refused $\mathrm{H}_{0}$} \\
\hline Control & Medium & & & \\
\hline Eksperimental & Medium & \multirow{2}{*}{17.535} & \multirow{2}{*}{.000} & \multirow{2}{*}{ Refused $\mathrm{H}_{0}$} \\
\hline Control & Low & & & \\
\hline Eksperimental & Low & \multirow{2}{*}{-29.302} & \multirow{2}{*}{.000} & \multirow{2}{*}{ Refused $\mathrm{H}_{0}$} \\
\hline Control & High & & & \\
\hline Eksperimental & Low & \multirow{2}{*}{-0.476} & \multirow{2}{*}{.639} & \multirow{2}{*}{ Accepted $\mathrm{H}_{0}$} \\
\hline Control & Medium & & & \\
\hline Eksperimental & Low & \multirow{2}{*}{1.501} & \multirow{2}{*}{.151} & \multirow{2}{*}{ Accepted $\mathrm{H}_{0}$} \\
\hline Control & Low & & & \\
\hline
\end{tabular}

Based on Table 1.3 the sig value is obtained. $<0.05$ then $\mathrm{H} 0$ is rejected. So that it can be concluded that 1) There is no difference in the increase in students 'mathematical reasoning abilities taught by Problem Based Learning (PBL) and conventional learning models, in terms of levels (high and high) rejected, 2) Increased students' mathematical reasoning abilities taught with models Learning Problem Based Learning (PBL) is better than conventional learning, in terms of level (high and medium) accepted, 3) Increased mathematical reasoning abilities of students taught with Problem Based Learning (PBL) learning models are better than conventional learning, in terms of level (high and low) are accepted, 4) Increased mathematical reasoning abilities of students taught with Problem Based Learning (PBL) learning models are better than conventional learning, in terms of levels (medium and high) accepted. 5) Increased students' mathematical reasoning abilities taught with a model of defense the teaching of Problem Based Learning (PBL) is better than conventional learning, in terms of level (moderate and moderate) received. 6) Increased mathematical reasoning abilities of students taught with Problem Based Learning (PBL) learning models are better than conventional learning, in terms of levels (medium and low) are accepted, 7) Increased mathematical reasoning abilities of students taught with Problem Based Learning (PBL) learning models are better than conventional learning, in terms of levels (low and high) accepted, 8) There is no difference in improvement in reasoning abilities Mathematically students taught with Problem Based Learning (PBL) learning models are better than conventional learning, in terms of levels (low and moderate) accepted, and 9) There is no difference in improvement in students' mathematical reasoning abilities taught with Problem Based Learning 
(PBL) learning models. ) and conventional learning, injected au from levels (low and low) are accepted.

Table 4. Average $\mathrm{N}$-gain difference test results Student learning independence reviewed based on Student Level

\begin{tabular}{|c|c|c|c|c|}
\hline Class & Group & t-Count & $\begin{array}{l}\text { Sig. } \\
\text { (2-tailed) }\end{array}$ & Conclusion \\
\hline Eksperimental & High & \multirow{2}{*}{0,774} & \multirow{2}{*}{.048} & \multirow{2}{*}{ Refused $\mathrm{H}_{0}$} \\
\hline Control & High & & & \\
\hline Eksperimental & High & \multirow{2}{*}{10,300} & \multirow{2}{*}{.000} & \multirow{2}{*}{ Refused $\mathrm{H}_{0}$} \\
\hline Control & Medium & & & \\
\hline Eksperimental & Medium & \multirow{2}{*}{$-11,770$} & \multirow{2}{*}{.000} & \multirow{2}{*}{ Refused $\mathrm{H}_{0}$} \\
\hline Control & High & & & \\
\hline Eksperimental & Medium & \multirow{2}{*}{$-1,391$} & \multirow{2}{*}{.072} & \multirow{2}{*}{ Accepted $\mathrm{H}_{0}$} \\
\hline Control & Medium & & & \\
\hline Eksperimental & Low & \multirow{2}{*}{$-22,587$} & \multirow{2}{*}{.000} & \multirow{2}{*}{ Refused $\mathrm{H}_{0}$} \\
\hline Control & High & & & \\
\hline Eksperimental & Low & \multirow{2}{*}{$-13,271$} & \multirow{2}{*}{.000} & \multirow{2}{*}{ Refused $\mathrm{H}_{0}$} \\
\hline Control & Medium & & & \\
\hline Eksperimental & Low & & & \\
\hline Control & Low & $-1,129$ & .075 & Accepted $\mathrm{H}_{0}$ \\
\hline
\end{tabular}

Table 5. Test for N-gain Difference Average Student Learning Independence reviewed based on Student Level

\begin{tabular}{|c|c|c|c|c|}
\hline Class & Group & $t^{\prime}$-Count & $\begin{array}{l}\text { Sig. } \\
\text { (2-tailed) }\end{array}$ & Conclusion \\
\hline Eksperimental & High & \multirow{2}{*}{22,8889} & \multirow{2}{*}{.000} & \multirow{2}{*}{ Refused $\mathrm{H}_{0}$} \\
\hline Control & Low & & & \\
\hline Eksperimental & Medium & \multirow{2}{*}{14,398} & \multirow{2}{*}{.000} & \multirow{2}{*}{ Refused $\mathrm{H}_{0}$} \\
\hline Control & Low & & & \\
\hline
\end{tabular}

Based on Table 4 and Table 5, the sig values are obtained. $<0.05$ then $\mathrm{H}_{0}$ is rejected. So that it can be concluded that 1) Increased student learning independence taught with Problem Based Learning (PBL) learning models is better than conventional learning, in terms of levels (high and high) accepted, 2) Increased student learning independence taught with Problem Based learning models Learning (PBL) is better than conventional learning, in terms of levels (high and medium) accepted, 3) Increased learning independence of students taught with Problem Based Learning (PBL) learning models is better than conventional learning, in terms of levels (high and low ) accepted, 4) Improvement of student learning independence taught with Problem Based Learning (PBL) learning models is better than conventional learning, in terms of levels (medium and high) accepted, 5) There is no difference in increasing student learning independence taught by learning models Problem Based Learning (P BL) and conventional learning, in terms of level (moderate and moderate) rejected, 6) Increased learning independence of students taught with Problem Based Learning (PBL) learning models is better than conventional learning, in terms of levels (medium and low) accepted, 7 ) Improvement of student learning independence taught with Problem Based Learning (PBL) learning models is better than conventional learning, in terms of levels (low and high) accepted, 8) Increased learning independence of students taught with Problem Based Learning (PBL) learning models more good than conventional learning, in terms of levels (low and medium) accepted, and 9) There is no difference in the increase in student learning independence taught with Problem Based Learning (PBL) learning models and conventional learning, in terms of levels (low and low) rejected.

\section{Discussion Increased Mathematical Reasoning Capability}

The results of data analysis both descriptive analysis and statistical tests showed that the increase in mathematical abilities of students who obtained learning with PBL approach was better than students who obtained conventional learning. This is very possible, because presenting contextual problems at the beginning of learning is one of the stimuli and triggers of students to think (Sugandi, 2013). PBL learning is a teaching approach that is emphasized in students. So students must be given the opportunity to construct mathematical knowledge, students rediscover mathematical ideas and concepts through exploration of problems in real contexts. Contextual learning starts from things that are close to the daily lives of students who are concrete. That way students will be interested in learning so that active and dynamic learning occurs because they know what they can learn and can imagine. This condition is as the result of research by Maidiyah (2009) which shows that the PBL approach can make students very enthusiastic in participating in learning activities and students are also interested in following the next learning.

The results of this study are in line with the research of Tohap (2002), namely there are differences between the average mathematical ability of students who get PBL learning with conventional learning, namely the average mathematical ability of students using the PBL approach is 54,009 while students using the conventional approach are 33,666. This means that students' mathematical abilities taught with the PBL approach are better than students taught with conventional learning. The results of research by Sofian (2011) also state that mathematics learning with a contextual approach is significantly better in improving students' mathematical abilities compared to conventional learning. In addition, the results of Efendi's (2014) study, Imawati (2008), Nurdalilah (2014), and Sembiring (2014) concluded that mathematical reasoning abilities can be improved by using creative and innovative learning approaches and requiring students to be more active and skilled in the learning process.

If observed from the results of data analysis, it was found that the learning approach factor had a significant influence on improving students' mathematical abilities. In other words, the mathematical ability of students who get learning with the PBL approach is better than students who get learning with conventional approaches. The different characteristics of the two learning approaches make it possible for students to have different abilities after participating in the learning process. Learning with the PBL approach challenges students to complete LKS 
independently, composes answers and draw conclusions. This activity causes students to develop higher thinking and reasoning abilities to investigate or analyze the information so that a solution can be formulated that must also be able to conclude on its own. In addition, students must also present their work and then be responded to by their friends from other groups. Students who learn with the PBL approach have more activity and creativity than students who learn with conventional learning so that their mathematical abilities are better than students in conventional classes. Learning with the PBL approach strongly requires students to think and reason, connect mathematical concepts, create and identify mathematical ideas, and think of the most appropriate and reasonable way to solve questions that have been formulated. This situation greatly allows students to reconstruct their thoughts and develop mathematical abilities.

\section{Enhancing the ability of student learning independence}

The results of data analysis both descriptive analysis and statistical tests showed that there were significant differences in the improvement of student learning independence between students who obtained learning with PBL and students who obtained conventional learning. The results of the data analysis also showed that improving the learning independence of students who obtained the PBL approach was significantly better than students who obtained the conventional approach. This is because in PBL learning, the first step that the teacher takes in the classroom is to develop students' thinking that learning is more meaningful by working alone, finding themselves, and constructing their own new knowledge and skills (Ministry of National Education, 2005). When students can associate material with their own experiences, they discover the meaning of the lesson and meaning gives them reason to learn. This encourages students to be independent in learning so that students will not feel hopeless in facing problems and choose a suitable strategy to solve the problem. In line with that, according to Fauzan (2013: 9) "When students work with contextual questions, they are encouraged and facilitated to find and use informal ideas they have in solving problems. Furthermore, they are also encouraged to exchange ideas, criticize the ideas of other students, and learn from the ideas of other students who they think are more appropriate. This condition on the one hand requires students' independence in learning mathematics".

These findings strengthen Surya (2013), Sugandi (2013), and Ratnaningsih (2007) who concluded that the contextual approach applied to mathematics learning can improve student learning independence. In addition, the results of this data analysis are also in line with the results of the study of Purnamasari (2014) which concluded that learning independence can be improved by using approaches and learning models and requiring students to be more active and skilled in the learning process.
If examined from the results of data analysis, it was found that learning with a contextual approach to mathematics learning encourages students to make connections between their knowledge and application in daily life, so students learn from experiencing themselves and can improve student learning motivation, enjoy learning independent and able to make decisions. Mathematics learning with the PBL approach takes place actively and interactively, students work on their own worksheets given in their groups and explain and give reasons for the answers made then other groups respond to them. Such activities give rise to the independence of learning and students 'confidence in their answers, understanding the answers of other students, agreeing with their friends' answers, expressing disapproval, looking for other alternative solutions, and reflecting on each step taken.

Overall, the increase in student learning independence in the experimental class (students who get learning with the PBL approach) is better than students in the control class (students who get learning using conventional approaches). However, not all students experience increased learning independence and the increase that occurs is also not too significant. There are some students who do not experience an increase in learning independence both in the experimental class and in the control class. This may be because the number of meetings is very limited and to improve the affective aspects of students is also not as easy as improving the cognitive aspects, it takes a long time to change the views or perceptions of students about mathematics. However, the number of students who did not experience an increase in student independence in the experimental class was less than the control class. Therefore, the learning approach factor is one of the most influential factors in increasing student learning independence. The application of the right approach such as the PBL approach in the learning process will make students become more interested in mathematics and will be more responsible for solving mathematical problems. This is in accordance with the observations of researchers during the learning process with the PBL approach, most students seemed enthusiastic when designing answers to the worksheets given even though there were also some who seemed to only accept what was done by their friends.

In general, students who receive learning with the PBL approach have a positive tendency towards learning independence. For example, strong determination to complete mathematical tasks together in the group, interest and desire to find something new, not relying on the teacher, discuss with each other in conducting LKS work, and be able to evaluate the results of learning.

\section{CONCLUSION}

Based on the results of the research and statistical analysis carried out, several conclusions can be given, 
among others: 1) Increased mathematical reasoning abilities of students who get learning with PBL approaches better than students who get learning with conventional approaches in terms of overall and initial abilities of students (high, moderate, low), except for comparison of low initial abilities in the experimental class and low initial ability of the control class, 2) Increased learning independence of students who obtain learning with the PBL approach better than students who obtain learning with conventional approaches in terms of overall and initial abilities students (high, medium, low).

Teachers should more often apply PBL learning models to SPLTV material so that it is fun and not monotonous so that it does not make students feel bored and feel frightened while attending mathematics learning.

\section{REFERENCES}

Ali, M, \& Asrori, M. (2010). Psikologi remaja. Jakarta: Bumi Aksara.

Amir, M.T. (2010). Inovasi pendidikan melalui problem based learning. Jakarta: Kencana Prenanda Media Group.

Arends, R.I. (2010). Learning to teach seventh edition. New York: The McGraw Hill Companies.

Arikunto, S. (2012). Prosedur penelitian : suatu pendekatan praktik. (Edisi Revisi). Jakarta : Rineka Cipta.

Arikunto, S. (2003). Prosedur penelitian suatu pendekatan praktek. Jakarta: Rineka Cipta.

Ario, M. (2015). Penalaran matematis dan mathematical habits of mind melalui pembelajaran berbasis masalah dan penemuan terbimbing. Edusentris, Jurnal Ilmu Pendidikan dan Pengajaran, 2(1), 34-46.

Bieda, K. N., Ji, X., Drwencke, J., \& Picard, A. (2014). Reasoning-and-proving opportunities in elementary mathematics textbooks. International Journal of Educational Research, 64, 71-80.

Depdiknas. (2012). KBBI pusat bahasa. Jakarta: PT Gramedia Pustaka Utama.

Gallagher, S (2015). Doing the math: calculating the role of evolution and enculturation in the origins of geometrical and mathematical reasoning. [versi elektronik]. Journal for Progress in Biophysics and Molecular Biology, 119, 341-346.

Mahardiyanti, T. (2014). Penerapan metode pembelajaran problem based learning (pbl) untuk meningkatkan kemampuan penalaran matematis siswa. Journal Ilmiah Pendidikan, 2(2), 142-149.

Mullis, I.V.S., Martin, M.O., Foy, P., \& Arora, A. (2012). TIMSS 2011 In-ternastional result in mathema-tics. chestnut hill, MA: TIMSS \& PIRLS International Study Center, Boston College.

NCTM. (2000). Principles and standards for school mathematics. Reston, VA: NCTM.

Novak, V. (2010). Reasoning about mathematical fuzzylogic and its future. [versi elektronik]. Journal of Fuzzy Sets and System, 19(2), 25-44.

Rizqi,N.R., \& Surya,E. (2017). An analysis of students' mathematical reasoning ability in viii grade of sabilina tembung junior high school. International Journal Of Advance Research And Innovative Ideas In Education (IJARIIE), 3(2).

Rusman.(2012). Model-model pembelajaran. Depok : PT Raja Grafindo Persada

Savery, J.R, \& Duffy, T.M. (2001). Problem based learning: An Introduction model and its Constructivist framework. [versi elektronik]. Journal CRLT Technical Report, 16(1), 1-17

Slameto. (2010). Belajar dan faktor-faktor yang mempengaruinya. Jakarta: Rineka Cipta.

Sudjana, N. (2011). Dasar-dasar proses belajar mengajar. Bandung: Sinar Baru Algensindo.

Sugandi, A.I (2013). Pengaruh pembelajaran berbasis masalah dengan setting kooperatif jigsaw terhadap kemandirian belajar siswa SMA. Jurnal Ilmiah Program Studi Matematika STKIP Siliwangi Bandung, 2 (2),3-5

Sugiyono. (2013). Metode penelitian pendidikan pendekatan kuantitatif, kualitatif, dan r\&d. Bandung: Alfabeta.

Suharti, A. (2013). Improvement of power mathmatical in learning math through learning model combined. International Journal of Science and Technology. 2(8), 576-582.

Suherman. (2003). Strategi pembelajaran matematika kontemporer. Bandung: JICA-IMSTEP Universitas Pendidikan Indonesia.

Sumarmo, U. (2010). Kemandirian belajar : apa, mengapa, dan bagaimana, dikembangkan pada peserta didik. Bandung: FMIPA UPI.

Sumartini, T.S. (2015). Peningkatan kemampuan penalaran matematis siswa melalui pembelajaran berbasis masalah. Jurnal Pendidikan Matematika, $5(1), 1-4$

Sundayana. (2010). Statistika penelitian pendidikan. STKIP Garut Press.

Suprijono, A. 2010. Cooperative learning. Yogyakarta: Pustaka Pelajar.

Turmudi. (2008). Landasan filosofis dan teoritis pembelajaran matematika (berparadigma exploratif 
dan investigatif). Jakarta: Lauser Cita Pustaka.

Uyanto. (2009). Pedoman analisis data dengan spss. Jakarta: Graha Ilmu.

Wena, M. (2009). Strategi pembelajaran inovatif kontemporer. Jakarta : Bumi Aksara.

Yasmin, M. (2011). Desain pembelajaran berbasis tingkat satuan pendidikan. Jakarta: Gaung Persada. 